純エタノール局注療法により止血治瘜し得た Dieulafoy’s

type と思われる十二指腸潰瘍の 1 例

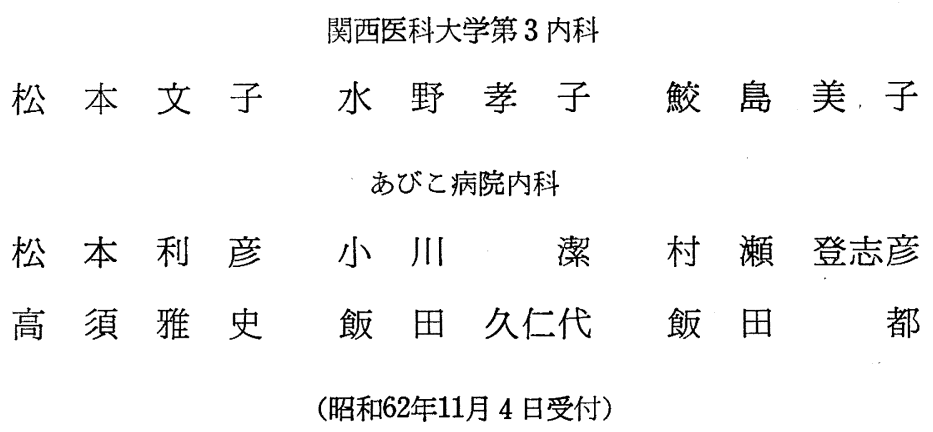

索引用語 : 出血性十二指腸潰瘍, Exulceratio simplex (Dieulafoy), 純エタノール局注療法

\section{I. 緒言}

上部消化管出血の原因疾患として，十二指腸潰瘍は欧 米では第 1 位, 我が国では第 2 位を占めている. 今回, 我々は出血性十二指腸潰湯のうち, きわめて稀な Dieulafoy's type (Exulceratio simplex 類似疾患, 以下 Es) と考元られ，純エタノール（以下 $\mathrm{EtOH)}$ 局注療法によ り止血治瘾し得た症例を経験したので報告する.

\section{II. 症例}

症例：33才 男性 会社員

主訴：タール便

既往歴：特記事項なし

家族歴：特記事項なし

膡好：酒 3〜4合/日 タバコ 20本/日

現病歴：昭和61年 4 月 7 日頃より, 食事に関係なく心䈑 部および背部痛を来したが放置していた４月10日午 後 8 時, 突然, 黑色の水椂下痢便が 2 回あり, 全身僚 急感も来したため 午後 9 時本院受診, 即日入院とな る. 尚, 経過中, 悪心 ・呕吐・食欲不振は自覚してい ない。

現症：身長 $172 \mathrm{~cm}$, 体重 $64 \mathrm{~kg}$ 意識清明, 血圧 $120 / 70$ $\mathrm{mmHg}$, 体温 $36.6^{\circ} \mathrm{C}$, 脈拍 $96 /$ 分 整, 皮虐, 結膜行貧 血を認める.心・肺に著变なし、腹部では心窩部から 右季肋部に圧痛を認めるが, 筋性防御や腹水はない。 四肢冷感，浮腫もない。

入院時検査成繶 : Table 1 亿示すように, 強度の筫血, BUN の上昇, 便潜血反応強陽性など 消化管出血を示
Table 1 Laboratory findings on admission

\begin{tabular}{|c|c|c|c|}
\hline \multicolumn{2}{|l|}{ Hematology } & \multicolumn{2}{|c|}{ Blood chemistry } \\
\hline $\mathrm{RBC}$ & $260 \times 10^{4} / \mathrm{mm}^{3}$ & GOT & $9 \mathrm{IU} / \ell$ \\
\hline $\mathrm{Hb}$ & $7.0 \mathrm{~g} / d \ell$ & GPT & $6 \mathrm{IU} / \ell$ \\
\hline $\mathrm{Ht}$ & $23.1 \%$ & $\mathrm{LDH}$ & $157 \mathrm{IU} / \ell$ \\
\hline WBC & $7500 / \mathrm{mm}^{3}$ & ALP & $55 \mathrm{IU} / \ell$ \\
\hline \multirow[t]{2}{*}{ Platelet } & $13 \times 10^{4} / \mathrm{mm}^{3}$ & LAP & $78 \mathrm{IU} / \ell$ \\
\hline & & BUN & $27 \mathrm{mg} / d \ell$ \\
\hline \multirow{2}{*}{\multicolumn{2}{|c|}{ Stool Exams. Occult blood(卅) }} & CRTN & $1.0 \mathrm{mg} / d \ell$ \\
\hline & & $\mathrm{Na}$ & $39 \mathrm{mEq} / \ell$ \\
\hline \multirow{4}{*}{\multicolumn{2}{|c|}{$\begin{aligned} \text { Urinalysis } & \text { Protein }(-) \\
& \text { Sugar }(-) \\
& \text { Sediment n.p. }\end{aligned}$}} & $\mathrm{K}$ & $.6 \mathrm{mEq} / \ell$ \\
\hline & & $\mathrm{Cl}$ & $02 \mathrm{mEq} / \ell$ \\
\hline & & $\mathrm{Fe}$ & $98 \mu \mathrm{g} / d \ell$ \\
\hline & & CEA & $0.5 \mathrm{ng} / \mathrm{ml}$ \\
\hline \multicolumn{2}{|c|}{ Chest $\mathrm{x}-\mathrm{p} \quad$ n. $\mathrm{p}$. } & \multicolumn{2}{|c|}{ Gastrin $80 \mathrm{pg} / \mathrm{m} l$} \\
\hline \multicolumn{2}{|c|}{$\begin{array}{l}\text { Abdominal } x-p \\
\text { ECG n.p. }\end{array}$} & $\mathrm{CRP}$ & $0.1 \mathrm{mg} / d \ell$ \\
\hline
\end{tabular}

唆する所見がみられた。ガストリン, CEA は正常 で, CRP は陰性であった.

経過：以上の所見より消化管出血が疑われたため, 絶食 とし, 輸液・輸血（赤血球濃厚液 $400 \mathrm{~m} l$ ) ・ 止血剂・ $\mathrm{H}_{2}$ 受容体拮抗刜投与など保存的治療を行った。第 2 病日第 1 回内視鏡検查を行ったところ, 食道には著变 なく, 胃では主に前庭部に凝血塊の付着をみたが潰瘍 なぞ明らかな出血性病变を認めなかった。 十二指腸で は球部後壁に山田II 型の隆起性病変があり, その中央 飞拍動的㴗出性出血を伴う径 $1 \mathrm{~mm}$ 程度の露出血管を認 めた（Fig. 1). 十二指腸下行脚以下は出血のため観 


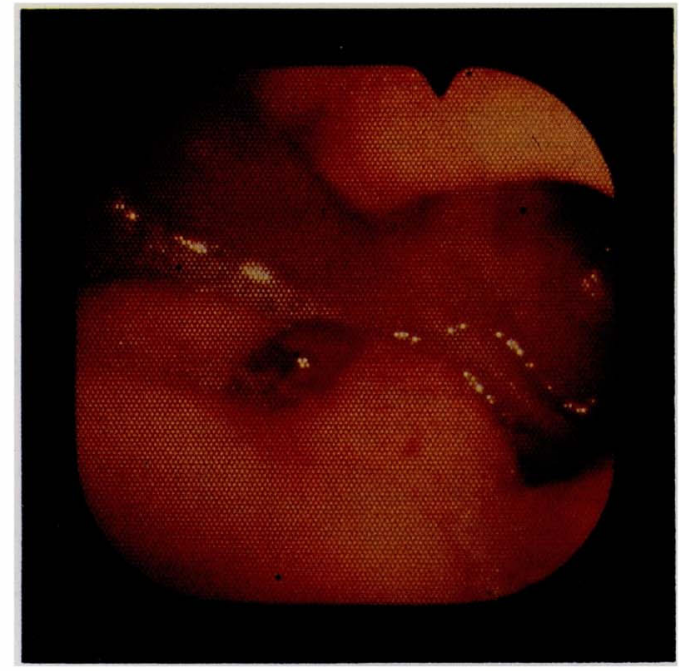

Fig. 1

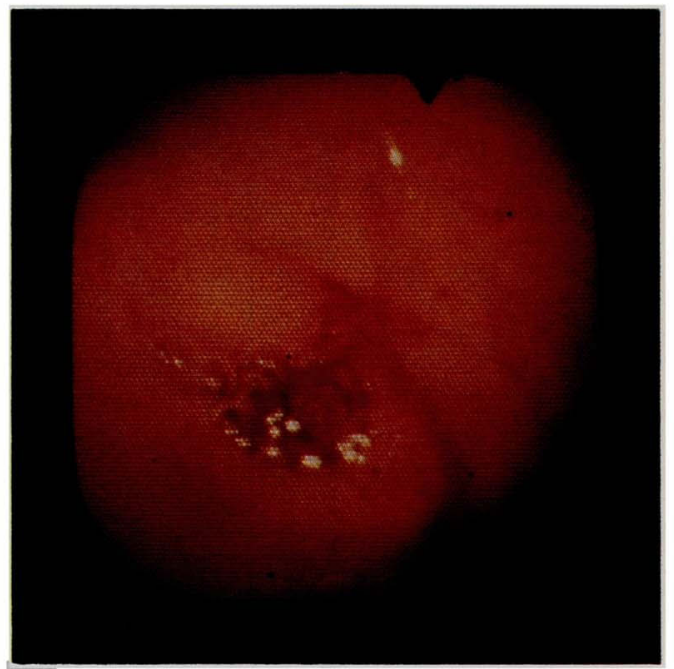

Fig. 2

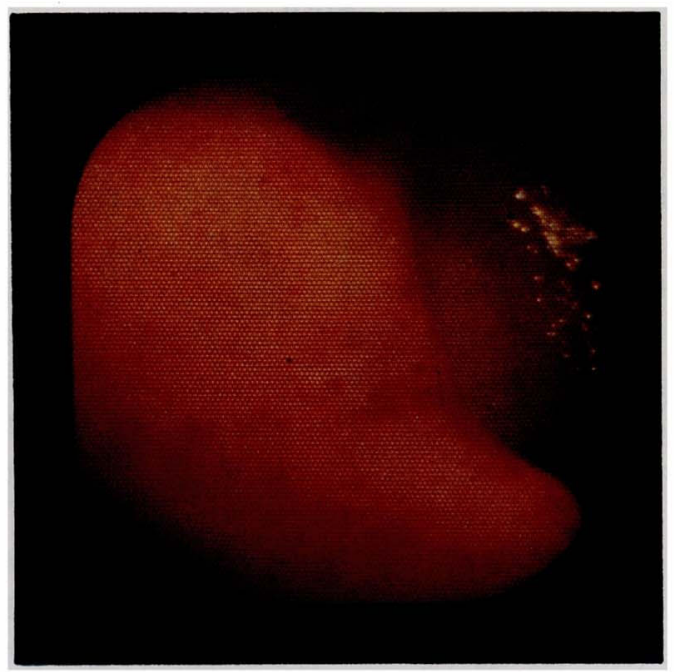

Fig. 3

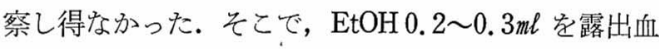
管周囲 3 カ所に局注したところ止血し得た. 止血後に は径 $5 \mathrm{~mm}$ 程度の粘膜欠損（U1II）を認めた（Fig. 2).その後上記保存療法を続けたところ, 第 3 病日よ り自他覚所見は改善し, 第 5 病日に行った内視鏡検查 では病巣に露出血管はなく, 小発赤斑のみとなってい た。以後,摂食を開始したが経過は順調で（Table 2)， 第16病日の内視鏡検查では潰瘍は瘢痕化 (Fig. 3 ) 乙 退院した.
III. 考案

上部消化管出血の原因疾患別頻度をみると, 欧米では 十二指腸潰瘍が第 1 位を占め, Palmer ${ }^{1)} 25 \%$, Crook ら 2) $40 \%$ と報告している. 我が国では胃潰瘍についで多 <, 西元寺 ${ }^{3)} 29.5 \%$, 佐藤ら $\left.{ }^{4}\right) 11.9 \%$ (269 例中22 例), Yamagiwa ら ${ }^{5)} 14.2 \%$ と報告している. これらの 十二指腸潰瘍には胃潰瘍と比較して以下のような差異・ 特徵がある. 
Table 2 Clinical course

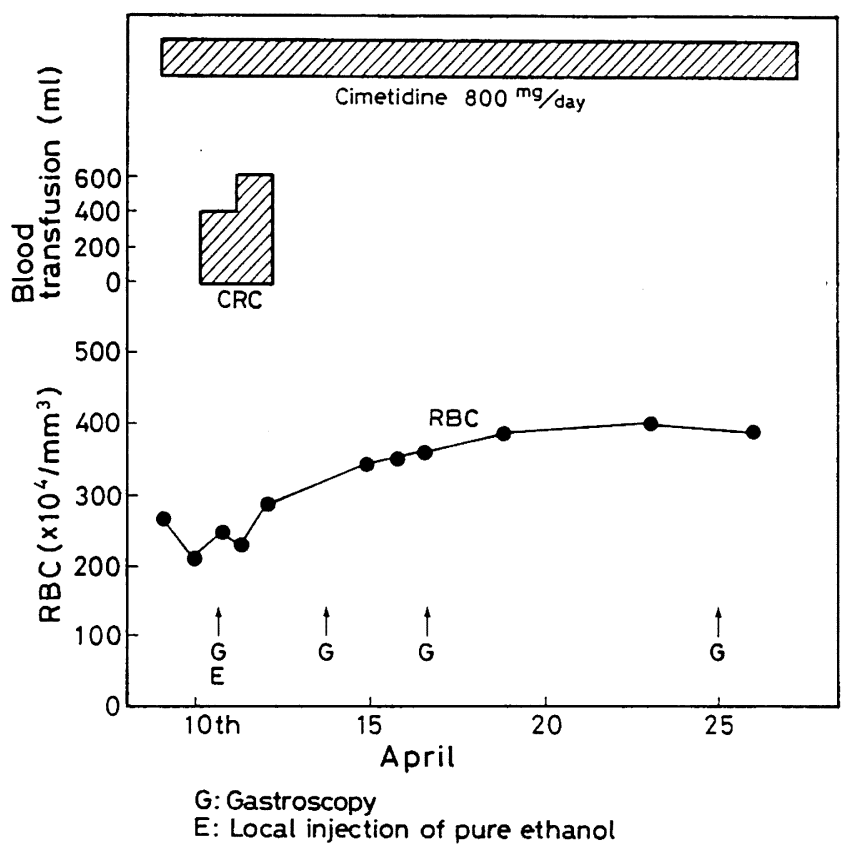

臨床症状に関して，一般に吐血は十二指腸空腸曲から 上部の出血にみられるとされているが, 出血性十二指腸 潰瘍では下血の頻度が高い3)5)6)。しかし，大量出血例 では吐血をみることが多いとする報告7) 8) と，逆化下血 の頻度がさらに高くなるという報告9'があり, 必ずしも 一致していない．また，十二指腸潰瘍は胃潰瘍に比べ大 量出血例が若干多いとも言われている9) 10)。これは主 訴が下血であることが多いので, 気付かれて診断・治療 されるまでに要する時間が長くなるためとされている.

十二指腸潰瘍は一般的に前壁に多いとされているが, その中でも出血性十二指腸潰瘍の好発部位について, 安 井10) は前壁 (50\%), ついで小彎(30\%)とする一方, 一 般の潰瘍の分布とほとえど变りがないため, 特に出血し 易い部位はないとしている. この点について Yamagiwa ら5) 湔壁に多く, 大量出血例では Kissing ulcers の 頻度が高いとし, 近藤ら 11$)$ は十二指腸潰瘍大量出血例 10例はいずれも後壁に病变を認めている.

つぎに，これらの出血性潰瘍の病理所見を検討した. 潰瘍の深さについて胃潰瘍では U1 II とIVの頻度が高い が, 十二指腸潰瘍では U1 II は少なく, U1 III や U1 IV を呈す深い潰瘍が多い10)，潰瘍面にみられる 露出血管 の有無について, 安井10) は胃潰瘍52\% (62病変中 32 病 変), 十二指腸潰瘍 $0 \%$ (20病変中なし), また藤堂ら12)
は内視鏡的に露出血管を確認し得た症例は胃潰瘍 $28 \%$ (81例中23例)，十二指腸潰喤 $4 \%$ (27例中 1 例） と報 告し，いずれも後者ではきわめて低頻度である.

以上の検討から, 出血性十二指腸潰瘍は下血を主訴と 乙, その出血形態から大量出血に陥りやすく, 特に好発 部位はない (大量出血例では後壁に多い). 病理所見では Ul III, U1 IV の深い潰瘍が多く, 露出血管を伴うこと は少いと言える.

今回我々の経験した症例は，十二指腸球部後壁に明ら かに動脈由来と判断乙得る拍動性出血を伴う露出血管 と, その周囲に小粘膜欠損 (U1 II 程度), がみられ臨床 的には安井 ${ }^{10}$ ) の判定基準 (赤血球数 $300 \times 10^{4}$ 以下, $\mathrm{Hb}$ $8.0 \mathrm{~g} / \mathrm{d} \ell$ 以下, Ht 30\%以下）に合致し, 大量出血があ った. そのため従来の十二指腸潰瘍からの出血とは若 干趣きを異にし， Dieulafoy 潰瘍に相当するものではな いかと考えた. 本症は1898年 Dieulafoy $\left.{ }^{13}\right)$ が胃上部に極 めて浅く，小さな粘膜欠損をみい出し，その底部を異常 走行する太い動脈の破綻により大量出血を来す疾患を Exulceratio simplex（Es）として発表したものである.

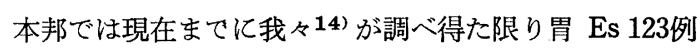
の報告があるが，一方，十二指腸 Es については，三宅 $ら^{15)}$ ，飯野ら ${ }^{16)} の 2$ 例をみるのみである. 自験例では 病理組織学的検索がないため確診は得られないが, 内視 
Table 3 Literature review of Dieulafoy's ulcer of the duodenum in Japan

\begin{tabular}{|c|c|c|c|c|}
\hline \multicolumn{2}{|c|}{ Authors (year) } & Miyake et al(1986) & Iino et al(1986) & Our case(1987) \\
\hline \multicolumn{2}{|c|}{ Age \& Sex } & 70 female & 14 male & 33 male \\
\hline \multicolumn{2}{|c|}{ Symptom } & tarry stool & hematoemesis & tarry stool \\
\hline \multirow{4}{*}{$\begin{array}{c}\text { Pathological } \\
\text { findings }\end{array}$} & Location of ulcer & ant. wall of SDA & bulb & post. wall of the bulb \\
\hline & Diameter of ulcer (mm) & $?$ & 8 & (5) \\
\hline & $\begin{array}{l}\text { Diameter of exposed } \\
\text { blood vessel }(\mathrm{mm})\end{array}$ & (1) & 0.2 & (1) \\
\hline & Depth of ulcer & U1 II & (shallow) & (U1 II) \\
\hline \multicolumn{2}{|c|}{ Therapy } & $\mathrm{EtOH}$ & HSE & $\mathrm{EtOH}$ \\
\hline
\end{tabular}

EtOH : Local injection of pure ethanol

HSE : Local injection of hypertonic saline epinephrine solution

( ) : Endoscopical findings

鏡所見から，十二指腸潰瘍の Dieulafoy's type または Es 類似疾患と考元た. これら 3 例を比較検討すると,

Table 3 亿示すとおりである. 出血形態は下血 2 例, 吐 血 1 例で, 病変はすべて球部であり, 好発部位は見出せ なかった．病変の大きさについて胃 Es と比較すると， 胃，Es の潰瘍径・露出血管径の平均がそれぞれ $5.5 \times$ $7.5 \mathrm{~mm}, 1.3 \mathrm{~mm}$ である14) ことから，露出血管は細い傾向 を認めた．治療について全例に内視鏡的局注止血法が試 みられている. その予後をみると，三宅ら15) の症例で は局注後22日目に再出血し死亡している. 飯野ら 16$) の$ 症例では局注後手術が行われている. 自験例では $\mathrm{EtOH}$ 局注により止血治療し得た. 出血性十二指腸潰瘍の長期

\section{文}

1) Palmer, E. D. : The vigorous diagnostic approach to upper-gastrointestinal tract hemorrhage. JAMA, 207, 1477 1480, 1969.

2) Crook, J.N. et al. : Upper gastrointestinal bleeding. Ann. Surg, 175, 771 779, 1972.

3）西元寺克禮ら：上部消化管出血例の検討一特飞出 血性消化性潰㕫について一 Kitasato Med., 6, 85 94, 1976.

4）佐藤 “彰ら：上部消化管出血の現状とその対応 一特に重症出血例の止血成績を考虑して一 Progress of Dig. Endosc., 27, 41 46, 1985.

5) Yamagiwa, H. et al. : Clinico-pathological study of the hemorrhagic gastric diseases. Mie Med,
予後について Serebro ら17) はかなりの率で再出血をみ たと報告していることから，我々の症例でも再出血の危 惧はある。伊東ら ${ }^{18)}$ は局注が適確に施行されれば再出 血はほとんどないが，止血後の経過観察を十分に行なう ことを強調している. そのため, 自験例も今後慎重に経 過観察を行なう予定である.

\section{IV. 結 語}

出血性十二指腸潰瘍のうち, きわめて稀な Dieulafoy's type と考えられ，EtOH 局注により止血治療し得た症 例を経験し，併せて，自験例を含む現在までに報告され た 3 症例について考察を加えた.

献

J., 23, 129 140, 1973.

6）江崎隆朗ら：上部消化管出血に対する緊急内視鏡 検査例の検討 Gastroenterol. Endosc., 23, 231 $\sim 239,1981$.

7）福岡秀治ら：胃十二指腸潰瘍出血例の治療方針一 とくに背景因子を中心に一 日消外会誌, 18, 1600 1608, 1985.

8）光永 篤ら：下血形態多い十二指腸疾患による出 血, Mod. Med, 14, 32〜35, 1985.

9）平岛 毅：胃・十二指腸潰揚よりの大量出血, 日 臨外会誌, 34, 26〜29, 1973.

10）安井 昭: 外科 Mook, 金原出版, 東京, 1980 , $12 \sim 28$. 
11）近藤良晴ら：上部消化管大量出血の診断と治療, 日消外会誌，12，106，1979.

12）藤堂嘢男ら：上部消化管出血の診断一救急医療に おける緊急内視鏡検査の意義一 救急医学, 2 , 15 23, 1978.

13) Dieulafoy, G. : Exulceratio simplex L'intervention chirurgicale dans les hématémèsis foudroyantes consécutives al' exulcération simplex de l'estomac, Bull de l' Acad de Med., 39, 49 84, 1898.

14）松本利彦ら：純エタノール局注療法により止血し 得た Exulceratio simplex (Dieulafoy) と思われ る 3 例一本邦報告123例の集計一 Gastroenterol,
Endosc. 29, 141 151, 1987.

15）三宅 周ら：十二指腸にみられた Dieulafoy 様潰 瘍の 1 例, Gastroenterol, Endosc., 28, 1911〜 1915, 1986.

16）飯野治彦ら：exulceratio simplex (Dieulafoy) of the bulb $の 1$ 例 第32回日本消化器内視鏡学会講 演予報集, 230, 1986.

17) Serebro, H. A., et al. : Late results of medical and surgical treatment of bleeding peptic ulcers. Lancet, 2(7462), 505 508, 1966.

18）伊東正一郎ら：上部消化管出血における純エ夕 ノール局注止血後の露出血管の内視 鏡的変化, Gastroenterol, Endosc., 26, 1673 1678, 1984. 


\title{
A Case of Duodenal Ulcer of Probable Dieulafoy's Type Cured by Endoscopic Local Injection of Pure Ethanol
}

\author{
Third Department of Internal Medicine, Kansai Medical University, \\ Moriguchi, Osaka 570 Japan \\ Fumiko Matsumoto, Takako Mizuno and Yoshiko Sameshima \\ Department of Internal Medicine, Abiko Hospital, \\ Osaka, Japan

\section{Toshihiko Matsumoto, Kiyoshi Ogawa, Toshihiko Murase,} \\ Masashi Takasu, Kuniyo Iida and Miyako Iida
}

\begin{abstract}
We successfully treated a patient with duodenal ulcer of probable Dieulafoy's type by local injection of pure ethanol (EtOH). The patient was a 33-year-old male with tarry stool and epigastric pain. On admission, severe anemia, increased BUN, and positive stool occult blood reaction were observed. Emergency endoscopy revealed no marked changes in the esophagus and stomach except exposed blood vessels with pulsating bleeding in the posterior wall of bulbus. Immediately, EtOH was locally injected, and the bleeding stopped. A small and shallow mucosal defect was detected at this site. No rebleeding was observed, and he was discharged on the 21st hospital day. Though no pathohistological evaluation was performed, a diagnosis of exulceratio simplex (Dieulafoy) was made endoscopically. To our knowledge, only 3 patients with duodenal Dieulafoy's ulcer including our patient have been reported. In addition, it is notable that bleeding stopped by local injection of EtOH.
\end{abstract}

